2. Ustawa $\mathrm{z}$ dnia 2 marca 2020 r. o szczególnych rozwiązaniach związanych z zapobieganiem, przeciwdziałaniem i zwalczaniem COVID-19, innych chorób zakaźnych oraz wywołanych nimi sytuacji kryzysowych. URL: https://isap.sejm.gov.pl/isap.nsf/ DocDetails.xsp?id=WDU20200000374.

3. Ustawa z dnia 31 marca 2020 r. o zmianie ustawy o systemie instytucji rozwoju. URL: https://isap.sejm.gov.pl/isap.nsf/DocDetails. xsp?id=WDU20200000569.

4. Bay, O., Thomson, G. (2013). Zarubizhni praktyky rozrobky stratehii rozvytku maloho pidpryiemnytstva na rehionalnomu rivni [Foreign practices of development of small business development strategies at the regional level]. Kyiv: K.I.S. 48 p. [in Ukrainian].

5. Bila, I.S., Salatiuk N.M. (2014). Svitovyi dosvid derzhavnoho rehuliuvannia pidpryiemnytstva [World experience of state regulation of entrepreneurship]. Problemy ekonomiky. No. 1. P. 26-30 [in Ukrainian].

6. Bondarchuk, M.Yu. (2014). Systemy pidtrymky maloho pidpryiemnytstva v Ukraini ta Respublitsi Polshcha [Support small business in Ukraine and the Republic of Poland]. Naukovyi visnyk Khersonskoho derzhavnoho universytetu. No. 9. P. 80-84 [in Ukrainian].

7. Diakunovskyi, O.Ye. (2017). Pravove rehuliuvannia zupynennia pidpryiemnytskoi diialnosti za initsiatyvoiu pidpryiemtsia: dosvid Respubliky Polshcha [Legal regulation suspension of business activity by entrepreneur initiative: the experience of Poland]. Naukovyi visnyk Khersonskoho derzhavnoho universytetu. Seriia "Iurydychni nauky”. No. 1. P. 109-114 [in Ukrainian].

8. Knyazkov, V.V. (2014). Pravove rehuliuvannia nadannia derzhavnoi finansovoi pidtrymky pidpryiemtsiam: problemy ta napriamky vdoskonalennia [Legal regulation of provision of state financial support to entrepreneurs: problems and ways of improvement]. Aktualni problemy derzhavy i prava. Vyp. 72. P. 220 - 224 [in Ukrainian].

9. Korotych,O.B.,OrelYu.L., RiabichkoO.V.(2010). Pidpryiemnytstvoyaksotsialno-ekonomichneyavyshche[The entrepreneurship as a socio-economic phenomenon]. Teoriia ta praktyka derzhavnoho upravlinnia. Vyp. 4. P. 211-216 [in Ukrainian].

10. Okrema dumka suddi Konstytutsiinoho Sudu Ukrainy Slidenka I.D. stosovno Rishennia Konstytutsiinoho Sudu Ukrainy u spravi za konstytutsiinym podanniam Verkhovnoho Sudu shchodo (...) Konstytutsiinyi Sud. Okrema dumka vid 28.08.2020. Ofitsiinyi visnyk Ukrainy. 2020. No. 76, st. 2433.

11. Ostapenko, N.V. (2012). Ekonomichna sutnist pidtrymky rozvytku maloho pidpryiemnytstva [The economic essence of supporting small business development]. Innovatsiina ekonomika. No. 3. P. 77-81 [in Ukrainian].

12. Ponomarev, V.P. (2000). Zashchyta ynteresov predpryiatyia kak osnova eho ekonomycheskoi bezopasnosty [Protection of the interests of the enterprise as the basis of its economic security]. Ekonomika. Menedzhment. Pidpryiemnytstvo: zb. nauk. prats Skhidnoukr. derzh. un-tu. No. 1. P. 27-35 [in Russian].

13. Pro vnesennia zmin do deiakykh zakonodavchykh aktiv Ukrainy, spriamovanykh na zabezpechennia dodatkovykh sotsialnykh ta ekonomichnykh harantii u zviazku z poshyrenniam koronavirusnoi khvoroby (COVID-19): Zakon Ukrainy vid 30.03.2020. No. 540-IX. Ofitsiinyi visnyk Ukrainy. 2020. No. 30, st. 1059.

14. Pro vnesennia zmin do Podatkovoho kodeksu Ukrainy ta inshykh zakoniv Ukrainy shchodo pidtrymky platnykiv podatkiv na period zdiisnennia zakhodiv, spriamovanykh na zapobihannia vynyknenniu i poshyrenniu koronavirusnoi khvoroby (COVID-19): Zakon Ukrainy vid 17.03.2020. No. 533-IX. Ofitsiinyi visnyk Ukrainy. 2020. No. 26, st. 958.

15. Pro vnesennia zmin do Podatkovoho kodeksu Ukrainy ta inshykh zakoniv Ukrainy shchodo dodatkovoi pidtrymky platnykiv podatkiv na period zdiisnennia zakhodiv, spriamovanykh na zapobihannia vynyknenniu i poshyrenniu koronavirusnoi khvoroby (COVID-19): Zakon Ukrainy vid 13.05.2020. No. 591-IX. Ofitsiinyi visnyk Ukrainy. 2020. No. 44, st. 1413.

16. Pro zapobihannia poshyrenniu na terytorii Ukrainy hostroi respiratornoi khvoroby COVID-19, sprychynenoi koronavirusom SARS-CoV-2: Postanova Kabinetu Ministriv Ukrainy vid 11.03.2020 No. 211. Ofitsiinyi visnyk Ukrainy. 2020. No. 23 , st. 896.

17. Trush, I.V. (2005). Hospodarsko-pravove zabezpechennia derzhavnoi pidtrymky maloho pidpryiemnytstva [A legal economic ensuring of a small enterprise state support in Ukraine]: avtoref. dys. ... kand. yuryd. nauk: 12.00.04. Donetsk, 2005.19 p. [in Ukraine].

18. Khomko, L.V., Kulhavets, Kh.Yu. (2016). Pravove rehuliuvannia pidpryiemnytskoi diialnosti: navchalniy posibnyk [Legal regulation of business activity] [in Ukrainian].

19. Chupryna, L.V., Yuzovytska, S.A. (2019). Svitovyi dosvid rozvytku maloho pidpryiemnytstva ta yoho vykorystannia v Ukraini [World experience in development of small enterprise and its development in Ukraine]. Infrastruktura rynku. Ekonomika ta upravlinnia pidpryiemstvamy. Vyp. 32. P. 264-270 [in Ukrainian].

\title{
DOI https://doi.org/10.51647/kelm.2020.3.1.32
}

\section{ВІЛЬНИЙ РОЗСУД У ДІЯЛЬНОСТІ ОРГАНІВ МІСЦЕВОГО САМОВРЯДУВАННЯ ЩОДО ВИРІШЕННЯ ЗЕМЕЛЬНИХ ПИТАНЬ ТА СПОСОБИ ЙОГО ОБМЕЖЕННЯ}

\author{
Владислав Залєвський \\ аспірант кафедри державно-правових дисизиплін \\ юридичного факультету \\ Харківського національного університету імені В.Н. Каразіна (Харків, Україна) \\ ORCID ID: 0000000234409440
}

Анотація. Статтю присвячено проблемі вільного розсуду і дискреційних повноважень у діяльності органів місцевого самоврядування щодо вирішення земельних питань. Показано, що специфікою реалізації дискреційних повноважень органами місцевого самоврядування у процесі вирішення земельних питань є наявність вільного розсуду двох видів, 
а саме інтелектуального і вольового. Перший реалізується під час підготовки проєкту рішення про надання дозволу на розроблення проєкту землеустрою щодо відведення земельної ділянки, а другий - під час голосування за проєкт відповідного рішення. Розглянуто можливості обмеження вільного розсуду в діяльності органів місцевого самоврядування під час вирішення земельних питань. Встановлено, що обмеження вільного розсуду здійснюється за допомогою встановлення виключного переліку підстав для ухвалення негативного рішення, запровадження принципу мовчазної згоди в разі порушення строків розгляду питання, а також можливості оскарження в суді негативного рішення.

Ключові слова: вільний розсуд, дискреційні повноваження, органи місцевого самоврядування, регулювання земельних відносин, обмеження вільного розсуду.

\title{
FREE DISCRETION IN THE ACTIVITY OF LOCAL SELF-GOVERNMENT BODIES TO RESOLVE LAND ISSUES AND WAYS TO RESTRICT IT
}

\author{
Vladyslav Zalievskyi \\ Graduate Student at the Department of State and Legal Disciplines \\ of the Faculty of Law \\ V.N. Karazin Kharkiv National University (Kharkiv, Ukraine) \\ ORCID ID: 0000000234409440
}

\begin{abstract}
The article is devoted to the problem of free discretion and discretionary powers in the activities of local self-government bodies in resolving land issues. It is shown that the specificity of discretionary powers exercise by local governments in the process of resolving land issues is the availability of two types free discretion, namely intellectual and volitional. The first is implemented during the preparation of the draft decision on granting permission to develop a land management project for the allocation of land, and the second is implemented during the vote for the draft decision. Possibilities of free discretion restriction in activity of local governments at the decision of land issues are considered. It is ascertained that the restriction of free discretion is carried out by establishing an exclusive list of grounds for a negative decision, the introduction of the acquiescence principle in case of the consideration terms violation, as well as the possibility of appealing a negative decision in court.

Key words: free discretion, discretionary powers, local governments, regulation of land relations, restriction of free discretion.

\section{SWOBODNA DYSKRECJA W DZIALANIACH JEDNOSTEK SAMORZĄDU TERYTORIALNEGO W ZAKRESIE ROZWIĄZYWANIA PROBLEMÓW LĄDOWYCH I SPOSOBÓW ICH OGRANICZANIA}

\author{
Vladyslav Zalievskyi \\ aspirant Katedry Dyscyplin Publiczno-Prawnych \\ Wydziału Prawa, \\ Charkowskiego Uniwersytetu Narodowego im. W.N. Karazina (Charków, Ukraina) \\ ORCID ID: 0000000234409440
}

\begin{abstract}
Adnotacja. Artykuł poświęcony jest problematyce wolnej dyskrecji i uprawnień dyskrecjonalnych w działaniach jednostek samorządu terytorialnego w zakresie rozwiązywania problemów lądowych. Wykazano, że specyfiką realizacji uprawnień dyskrecjonalnych przez jednostki samorządu terytorialnego w procesie rozwiązywania problemów lądowych jest posiadanie wolnej dyskrecji dwóch rodzajów, a mianowicie intelektualnej i wolicjonalnej. Pierwszy realizowany jest podczas przygotowywania projektu decyzji o udzieleniu pozwolenia na opracowanie projektu zagospodarowania przestrzennego w zakresie zagospodarowania terenu, a drugi - podczas głosowania nad projektem stosownej decyzji. Rozważono możliwości ograniczenia swobodnej dyskrecji w działalności jednostek samorządu terytorialnego przy rozwiązywaniu problemów lądowych. Ustalono, że ograniczenie wolnej dyskrecji odbywa się poprzez ustanowienie wyłącznej listy podstaw do podjęcia decyzji negatywnej, wprowadzenie zasady milczącej zgody w przypadku naruszenia terminu rozpatrzenia sprawy, a także możliwość odwołania się do sądu decyzji negatywnej.

Słowa kluczowe: wolna dyskrecja, uprawnienia dyskrecjonalne, jednostki samorządu terytorialnego, regulacja stosunków lądowych, ograniczenie wolnej dyskrecji.

Вступ. Однією з найбільш поширених проблем у сфері земельних відносин є проблема реалізації дискреційних повноважень органів місцевого самоврядування під час вирішення земельних питань, зокрема відчуження земельних ділянок. Обмеженість земельних ресурсів, величезна кількість тих, хто бажає отримати земельні ділянки у власність, недосконалість чинного законодавства призводять до виникнення великої кількості спорів стосовно реалізації повноважень органів місцевого самоврядування в цій сфері. Проблема полягає в тому, що вільний розсуд органів місцевого самоврядування, притаманний їм через природу самоврядування, має бути узгоджений із необхідністю забезпечення прав і свобод людини і громадянина, проте механізми такого узгодження не є досконалими, що підтверджується відповідною судовою практикою. Натомість, як зазначають науковці, дослідження реалізації дискреційних повноважень колегіальними суб'єктами дозволяють звернути
\end{abstract}


увагу на те, що нині у відповідних суб'єктів є необмежена дискреційна компетенція. Відсутність регламентації здійснення ними таких повноважень дозволяє довільно використовувати свої управлінські функції та збільшує корупційний чинник у процесі їх виконання (Цвіркун, 2008: 76).

Основна частина. Проблемам вільного розсуду в діяльності публічної адміністрації та, відповідно, дискреційним повноваженням присвячено досить багато наукових праць. У різні часи відповідна тематика досліджувалась В.Б. Авер'яновим, О.Ф. Андрійко, Н.О. Армаш, Ю.П. Битяком, Д.І. Голосніченком, Л.С. Кисиль, О.С. Лагодою, С.А. Резановим, М.Б. Рісним, А.О. Селівановим, Г.Й. Ткач та багатьма іншими. Можна сказати, що загальна теорія дискреційних повноважень та вільного розсуду в діяльності суб'єктів публічної адміністрації є добре розробленою, зокрема в окремих прикладних сферах, в адміністративному судочинстві також. Проте у сфері діяльності органів місцевого самоврядування, пов'язаної з вирішенням земельних питань, проблема є малодослідженою.

Метою статті $\epsilon$ аналіз повноважень органів місцевого самоврядування щодо вирішення земельних питань 3 погляду їхньої дискреційності, а також визначення способів обмеження вільного розсуду в їхній діяльності.

Попри значну кількість наукових публікації, присвячених проблемам реалізації дискреційних повноважень, базовими положеннями, що перебувають в основі розуміння змісту дискреційних повноважень, є положення рекомендацій Комітету міністрів Ради Європи стосовно здійснення адміністративними органами влади дискреційних повноважень. Відповідно до цих рекомендацій, під дискреційними повноваженнями варто розуміти повноваження, які адміністративний орган, який ухвалює рішення, може здійснювати 3 певною свободою розсуду (рекомендації Комітету міністрів Ради Свропи № R (80) 2, 1980 р.). У вітчизняному законодавстві термін «дискреційні повноваження» уживався в Методології проведення антикорупційної експертизи проєктів нормативно-правових актів. Відповідно до цього документа, дискреційні повноваження - сукупність прав і обов'язків державних органів, їх посадових та службових осіб, що дають можливість на власний розсуд визначити повністю або частково зміст рішення або вибрати один із кількох варіантів ухвалення рішень, передбачених проєктом акта (Постанова КМУ, 2009: 81).

Отже, ключовим моментом дискреційних повноважень є вільний (власний, свободний) розсуд носія відповідних владних повноважень. Така ж думка панує й серед науковців, зокрема, А.О. Селіванов уважає, що державний розсуд можна схарактеризувати як повноваження на вільний вибір того варіанта поведінки (діiі), який найбільше відповідав би конкретним правовим умовам реалізації суб'єктом своєї компетенції (Селіванов, 2000: 68). Для колегіальних органів місцевого самоврядування вільний розсуд закладено в нормативному визначенні поняття місцевого самоврядування. Відповідно до ст. 2 Закону України «Про місцеве самоврядування», місцеве самоврядування в Україні - це гарантоване державою право та реальна здатність територіальної громади - жителів села чи добровільного об'єднання в сільську громаду жителів кількох сіл, селища, міста - самостійно або під відповідальність органів та посадових осіб місцевого самоврядування вирішувати питання місцевого значення в межах Конституції і законів України (Закон «Про місцеве самоврядування», 1997: 170). Вирішувати щось самостійно фактично й означає робити це на власний розсуд.

Право на власний розсуд підсилюється і способом ухвалення рішень основними органами місцевого самоврядування - місцевими радами. Відповідно до ст. 59 Закону України «Про місцеве самоврядування», рішення ради ухвалюється на їі пленарному засіданні після обговорення більшістю депутатів від загального складу ради, крім випадків, передбачених цим Законом. Рішення ради ухвалюються відкритим поіменним голосуванням, окрім випадків, передбачених у п. п. 4 і 16 ст. 26, п. п. 1, 29 і 31 ст. 43, ст. ст. 55, 56 цього Закону, у яких рішення ухвалюються таємним голосуванням. Тобто для ухвалення того чи іншого рішення шляхом голосування кожний депутат має визначитись на власний розсуд підтримувати відповідне рішення чи ні. Крім того, у ч. 6 ст. 60 цього ж Закону зазначено, що доцільність, порядок та умови відчуження об’єктів права комунальної власності визначаються відповідною радою.

Як зазначає М.О. Баймуратов, дискреційні повноваження органів місцевого самоврядування виникають на стику трьох складових частин: 1) наявності специфічних інтересів територіальної спільноти та їі членів, що пов'язані з їхніми індивідуальними, груповими, колективними, віковими, статевими, професійними, рольовими й іншими екзистенційними потребами та які формуються через складну та багаторівневу соціальнонормативну систему імпресій, інтенцій, життєвих устремлінь, потреб, - а у підсумку - через соціалізацію особистості; 2) обєктивації й усвідомлення державою та соціумом необхідності наявності в органів місцевого самоврядування відповідних - реальних, оптимальних, самодостатніх, ефективних, фінансово та ресурсно забезпечених повноважень; 3) трансформації сфери місцевого самоврядування з переважно сфери самоорганізації населення в більш широку сферу - сферу реалізації конституційних прав, свобод і обов'язків, які завдяки домінантній локальній ознаці їх реалізації й отримання соціального ефекту перетворюються на муніципальні права особи, людини, члена територіального колективу (Баймуратов, 2019: 33-34).

Розглянемо $з$ погляду дискреційності повноважень окремі процедури надання органами місцевого самоврядування земельних ділянок у власність громадянам відповідно до норм Земельного кодексу України. Відповідно до ч. ч. 6, 7 ст. 118 Земельного кодексу України (Земельний кодекс України, 2001: 27), громадяни, зацікавлені в одержанні безоплатно у власність земельної ділянки із земель комунальної власності для ведення фермерського господарства, ведення особистого селянського господарства, ведення садівництва, будівництва й обслуговування жилого будинку, господарських будівель і споруд (присадибної ділянки), індивідуального дачного будівництва, будівництва індивідуальних гаражів у межах норм безоплатної приватизації, подають 
клопотання до відповідного органу місцевого самоврядування, який передає земельні ділянки державної чи комунальної власності у власність відповідно до повноважень, визначених ст. 122 цього Кодексу. У клопотанні зазначаються цільове призначення земельної ділянки та їі орієнтовні розміри. До клопотання додаються графічні матеріали, на яких зазначено бажане місцерозташування земельної ділянки, погодження землекористувача (у разі вилучення земельної ділянки, що перебуває в користуванні інших осіб) та документи, що підтверджують досвід роботи в сільському господарстві або наявність освіти, здобутої в аграрному навчальному закладі (у разі надання земельної ділянки для ведення фермерського господарства).

Відповідний орган місцевого самоврядування, який передає земельні ділянки комунальної власності у власність відповідно до повноважень, визначених ст. 122 цього Кодексу, розглядає клопотання в місячний строк і дає дозвіл на розроблення проєкту землеустрою щодо відведення земельної ділянки або надає мотивовану відмову. Підставою для відмови в наданні такого дозволу може бути лише невідповідність місцерозташування об'єкта вимогам законів, ухвалених відповідно до них нормативно-правових актів, генеральних планів населених пунктів та іншої містобудівної документації, схем землеустрою і техніко-економічних обгрунтувань використання й охорони земель адміністративно-територіальних одиниць, проєктів землеустрою щодо впорядкування територій населених пунктів, затверджених у встановленому законом порядку.

Як випливає зі змісту наведених норм, тут має місце одразу два прояви дискреційних повноважень органу місцевого самоврядування, а саме місцевої ради, яка відповідно до ст. 122 Земельного кодексу України уповноважена вирішувати дані питання. Перший прояв стосується змісту рішення про надання дозволу на розроблення проєкту землеустрою щодо відведення земельної ділянки чи про відмову в наданні такого дозволу.

На перший погляд дискреційні повноваження органу місцевого самоврядування під час вирішення питання щодо надання дозволу на розроблення проєкту землеустрою обмежені виключним переліком підстав для відмови. Але лексична конструкція «підставою відмови в наданні такого дозволу може бути <...> охоплює й таку ситуацію, коли орган місцевого самоврядування може надати дозвіл навіть у разі наявності окремих підстав для відмови в його наданні. Тобто в таку лексичну конструкцію закладені певна диспозитивність та нормативна невизначеність. Очевидно, щоб зробити зазначений перелік підстав імперативним, необхідно було б використати іншу лексичну конструкцію, а саме вказати, що за наявності перелічених підстав дозвіл на розроблення проєкту землеустрою щодо відведення земельної ділянки не надається.

Зміст рішення відображається у проєкті рішення місцевої ради, який виноситься на голосування на пленарному засіданні сесії відповідної ради. I тут проявляється другий аспект дискреційних повноважень місцевих рад. Проєкт рішення про надання дозволу на розроблення проєкту землеустрою під час його розгляду та голосування може не отримати кількості голосів депутатів, необхідної для його ухвалення Тобто в голосуванні під час пленарних засідань у місцевих радах завжди наявний вільний розсуд депутатів, що зумовлено колегіальним способом ухвалення рішень і природою місцевого самоврядування. Такий вільний розсуд проявляється в усіх без винятку справах, які вирішуються колегіальними органами місцевого самоврядування.

Свого часу Ю.Г. Барабаш зазначав, що дискреція передбачає одночасне поєднання двох елементів: вольового, який включає в себе вільний розсуд, та інтелектуального (морально-правовий), який означає використання дискреційних повноважень «за здоровим глуздом» (Барабаш, 2007: 49-54). У наведеному вище прикладі ми маємо справу як раз із такими проявами дискреції, проте рознесеними в часі. Інтелектуальна дискреція, або дискреція здорового глузду, проявляється на стадії підготовки проєкту рішення про надання дозволу на розроблення проєкту землеустрою щодо відведення земельної ділянки. На стадії ухвалення рішення проявляється вольова дискреція.

Безумовно, наявність вільного розсуду у процедурах ухвалення рішень колегіальними органами місцевого самоврядування створює, з одного боку, корупційний ризик, а з іншого - порушує принцип правової визначеності. Як зазначають дослідники, необхідність обмеження дискреційних повноважень та сваволі держави щодо прав людини історично зумовила таку вимогу як невід’ємну складову частину принципу верховенства права. Нині неможливо уявити демократичні органи державної влади як з абсолютними повноваженнями, так і цілком позбавлені певного розсуду. Саме тому головним завданням права є вироблення чітких меж застосування дискреційних повноважень (Венгер, 2013: 49-54). Дане твердження є абсолютно справедливим не лише для сфери діяльності державних органів, але й для колегіальних органів місцевого самоврядування.

Оскільки в діяльності органів місцевого самоврядування щодо вирішення земельних питань мають місце два види вільного розсуду, отже, і два види дискреційних повноважень, то механізми відповідних обмежень мають існувати щодо обох.

Що стосується обмежень інтелектуальної дискреції, то в розглянутому нами прикладі такі обмеження мають місце, хоча й не в достатньому обсязі. Першим обмеженням можна вважати те, що ст. 118 визначено виключний перелік підстав для відмови в наданні дозволу щодо розроблення проєкту землеустрою щодо відведення земельної ділянки. Друге обмеження міститься у ч. 7 ст. 118 Земельного кодексу України і стосується випадку порушення строку ухвалення відповідного рішення. Так, відповідно до абзацу третього ч. 7 згаданої статті, якщо в місячний строк із дня реєстрації клопотання орган місцевого самоврядування, який передає земельні ділянки комунальної власності у власність відповідно до повноважень, визначених ст. 122 цього Кодексу, не надав дозволу на розроблення проєкту землеустрою щодо відведення земельної ділянки або мотивованої відмови в його наданні, то особа, зацікавлена в одержанні безоплатно у власність земельної ділянки iз земель комунальної власності, у місячний строк із дня закінчення зазначеного строку має право замовити 
розроблення проєкту землеустрою щодо відведення земельної ділянки без надання такого дозволу, про що письмово повідомляє орган місцевого самоврядування.

Дана норма була введена до Земельного кодексу Законом України «Про внесення змін до деяких законодавчих актів України щодо вдосконалення процедури відведення земельних ділянок» від 2 липня 2013 р. № 366-VII (Про внесення змін, 2013: 1185), а цей Закон було розроблено, серед іншого, 3 метою вдосконалення процедури відведення земельних ділянок через запровадження принципу мовчазної згоди на етапі отримання дозволу на розроблення документації із землеустрою.

На нашу думку, у даному разі принцип мовчазної згоди застосовано не зовсім коректно, оскільки відкритим залишається питання про необхідність отримання від органу місцевого самоврядування відповідного дозволу навіть після спливу зазначеного місячного строку. Для повноти правового регулювання в даному разі необхідно було б додати, якщо в місячний строк із дня реєстрації клопотання орган місцевого самоврядування не надав дозволу на розроблення проєкту землеустрою щодо відведення земельної ділянки або мотивованої відмови в його наданні, то такий дозвіл уважається наданим. У такому разі конструкція принципу мовчазної згоди у ст. 118 Земельного кодексу України була б завершеною і досконалою.

Що ж стосується обмеження вольової дискреції, то тут ситуація є набагато складнішою. Відповідно до ч. 10 ст. 118 Земельного кодексу України, відмова органу виконавчої влади чи органу місцевого самоврядування в передачі земельної ділянки у власність або залишення клопотання без розгляду можуть бути оскаржені в суді. Проте через правовий статус депутата місцевої ради його неможливо змусити голосувати тим чи іншим чином, навіть на виконання рішення суду. Відповідно до ч. 2 ст. 59 Закону України «Про місцеве самоврядування в Україні», рішення ради ухвалюється на ії пленарному засіданні після обговорення більшістю депутатів від загального складу ради, крім випадків, передбачених цим Законом. Інших способів ухвалення рішень місцевими радами Законом не передбачено, тому суд може зобов'язати раду розглянути рішення, наприклад, про затвердження проєкту землеустрою щодо відведення земельної ділянки та надання земельної ділянки у власність, але законодавчо визначеного механізму примусового виконання такого рішення нині немає. Проте така ситуація є прямим порушенням принципу правової визначеності. Зазначений принцип безпосередньо не представлений у законодавстві України, проте його зміст у різних аспектах використовується у практиці Конституційного Суду України (Гультай, 2012: 83-93).

У європейській правовій доктрині принцип правової визначеності розуміється як зобов'язання державних владних органів забезпечити легкість з'ясування права тими, до кого воно застосовується, і набуття останніми можливості, у разі необхідності, скористатися правом, як і способом, за допомогою якого воно буде підлягати застосуванню і тлумаченню. Інший аспект поняття принципу правової визначеності має вигляд принципів, згідно з якими закон не має зворотної сили та не діє перехідне право. Перший принцип є спільним фактично для всіх держав-членів. Як ухвалив Суд Європейського Союзу в рішенні у справі Racke, його основна мета полягає в забезпеченні того, що жодна з норм, які ухвалюють державні органи влади, не може бути застосована до не поінформованих про неї. Однак у тому самому рішенні стверджується, що застосування зворотної сили норми допускається у виняткових випадках, а саме: якщо цього вимагають цілі, яких вона має досягти, і забезпечує повагу до законних очікувань тих, на кого вона впливає. Принцип законних очікувань $є$ наслідком принципу правової визначеності. Він спрямований на те, щоб у випадках, коли фізична особа переконана, що досягне певного результату, якщо буде діяти відповідно до норм правової системи, забезпечити захист цих очікувань (Богачова, 2013: 2-3).

Саме в останньому контексті, тобто в контексті законних очікувань, для нас і $є$ цікавим зазначений принцип. Для його повноцінної реалізації, на нашу думку, варто запровадити положення, відповідно до якого невиконання органом місцевого самоврядування рішення суду, яким орган місцевого самоврядування зобов'язується розглянути певне рішення, зокрема у сфері регулювання земельних відносин, є підставою для дострокового припинення повноважень такого органу місцевого самоврядування. Такий крок $є$ виправданим з погляду персоналізації відповідальності за невиконання судових рішень.

Висновки. У підсумку можна констатувати, що специфікою реалізації дискреційних повноважень органами місцевого самоврядування у процесі вирішення земельних питань є наявність вільного розсуду двох видів, а саме інтелектуального і вольового. Перший реалізується під час підготовки проєкту рішення про надання дозволу на розроблення проєкту землеустрою щодо відведення земельної ділянки, а другий - під час голосування за проєкт відповідного рішення. Обмеження вільного розсуду здійснюється за допомогою встановлення виключного переліку підстав для ухвалення негативного рішення, запровадження принципу мовчазної згоди в разі порушення строків розгляду питання, а також можливості оскарження в суді негативного рішення. У зв'язку із цим потребує подальшого наукового опрацювання проблема виконання судових рішень колегіальними органами місцевого самоврядування.

\section{Список використаних джерел:}

1. Цвіркун Ю.І. До питання реалізації дискреційних повноважень колегіальними суб'єктами публічної адміністрації. Jurnalul juridic naţional: teorie şi practică. 2018. № 2. Ч. 2. C. 73-77. URL: http://www.jurnaluljuridic.in.ua/ archive/2018/2/part_2/16.pdf.

2. Рекомендації Комітету Міністрів Ради Європи № R (80) 2 стосовно здійснення адміністративними органами влади дискреційних повноважень від 11 березня 1980 р.

3. Про затвердження Методології проведення антикорупційної експертизи проектів нормативно-правових актів : постанова Кабінету Міністрів України від 8 грудня 2009 р. № 1346. Офіиійний вісник України. 2009. № 97. С. 81. Ст. 3356.

4. Селіванов А.О. Адміністративний процес в Україні: реальність і перспективи розвитку правових доктрин. Київ : Ін Юре, 2000. 68 c. 
5. Про місцеве самоврядування в Україні : Закон України від 21 травня 1997 р. № 280/97-ВР. Вiдомості Верховної Ради України. 1997. № 24. Ст. 170.

6. Баймуратов М.О., Боярський О.О. Дискреційні повноваження органів місцевого самоврядування в сфері захисту прав людини: методологічні підходи до розуміння та визначення. Публічне право. 2019. № 2. С. 31-41. URL: http://nbuv.gov.ua/UJRN/pp 201926.

7. Земельний кодекс України : Закон України від 25 жовтня 2001 р. № 2768-III. Відомості Верховної Ради Украӥни. 2002. № № 3-4. Ст. 27.

8. Барабаш Ю.Г. Дискреційні повноваження вищих органів влади: правова природа та умови ефективного застосування. Університетські наукові записки. 2007. № 4 (24). С. 49-54.

9. Венгер В.М. Обмеження дискреційних повноважень як складова принципу верховенства права. Наукові записки Наиіонального університету «Києво-Могилянська академія». Серія «Юридичні науки». 2013. Т. 144-145. С. $49-54$. URL: http://nbuv.gov.ua/UJRN/NaUKMAun_2013_144-145_13.

10. Про внесення змін до деяких законодавчих актів України щодо вдосконалення процедури відведення земельних ділянок : Закон України від 2 липня 2013 р. № 366-VII. Відомості Верховної Ради України. 2014. № 17. C. 1185. Ст. 587.

11. Гультай М., Кияниця І. Правова визначеність у рішеннях Конституційного Суду України. Вісник Конституційного Суду України. 2012. № 5. С. 83-93.

12. Богачова Л.Л. Принцип правової визначеності в європейському і національному праві (змістовна характеристика). Теорія і практика правознавства. 2013. Вип. 2. URL: http://nbuv.gov.ua/UJRN/tipp_2013_2_74.

\section{References:}

1. Tsvirkun Yu. Do pytannia realizatsii dyskretsiinykh povnovazhen kolehialnymy subiektamy publichnoi administratsii [On the issue of exercise of discretionary powers by collegial subjects of public administration] / Jurnalul juridic naţional: teorie şi practică. 2018. № 2. ch. 2. S. 7377. Rezhym dostupu: http://www.jurnaluljuridic.in.ua/archive/2018/2/part_2/16.pdf.

2. Rekomendatsii Komitetu Ministriv Rady Yevropy № R (80) 2 stosovno zdiisnennia administratyvnymy orhanamy vlady dyskretsiinykh povnovazhen vid 11.03.1980 [Recommendations of the Committee of Ministers of the Council of Europe № R (80) 2 concerning the exercise by the administrative authorities of discretionary powers of 11.03.1980].

3. Pro zatverdzhennia Metodolohii provedennia antykoruptsiinoi ekspertyzy proektiv normatyvno-pravovykh aktiv [On approval of the Methodology for conducting anti-corruption examination of draft regulations]. Postanova Kabinetu Ministriv Ukrainy vid 8 hrudnia 2009 roku № 1346 / Ofitsiinyi visnyk Ukrainy vid 25.12.2009 - 2009 r. № 97, stor. 81, stattia 3356.

4. Selivanov A.O. Administratyvnyi protses v Ukraini: realnist i perspektyvy rozvytku pravovykh doktryn [Administrative process in Ukraine: reality and prospects of legal doctrines development] / A.O. Selivanov. - K. : In Yure, 2000 . - 68 s.

5. Pro mistseve samovriaduvannia v Ukraini. Zakon Ukrainy vid 21 travnia 1997 roku № 280/97-VR [On local selfgovernment in Ukraine. Law of Ukraine of May 21, 1997 № 280/97-B] / Vidomosti Verkhovnoi Rady Ukrainy (VVR), 1997, № 24, st. 170.

6. Baimuratov M.O. Dyskretsiini povnovazhennia orhaniv mistsevoho samovriaduvannia v sferi zakhystu prav liudyny: metodolohichni pidkhody do rozuminnia ta vyznachennia [Discretionary powers of local governments in the field of human rights protection: methodological approaches to understanding and defining] / M.O. Baimuratov, O.O. Boiarskyi // Publichne pravo. - 2019. - № 2. - S. 31-41. - Rezhym dostupu: http://nbuv.gov.ua/UJRN/pp 201926.

7. Zemelnyi kodeks Ukrainy. Zakon Ukrainy vid 25 zhovtnia 2001 roku № 2768-III [Land Code of Ukraine. Law of Ukraine of October 25, 2001 № 2768-III]. Vidomosti Verkhovnoi Rady Ukrainy. 2002. № 3-4. st.27

8. Barabash Yu.H. Dyskretsiini povnovazhennia vyshchykh orhaniv vlady: pravova pryroda ta umovy efektyvnoho zastosuvannia [Discretionary powers of higher authorities: legal nature and conditions of effective application] / Yu.H. Barabash // Universytetski naukovi zapysky. - 2007. - № 4 (24). - S. 49-54.

9. Venher V.M. Obmezhennia dyskretsiinykh povnovazhen yak skladova pryntsypu verkhovenstva prava / V.M. Venher // Naukovi zapysky NaUKMA. Yurydychni nauky. - 2013. - T. 144-145. - S. 49-54. - Rezhym dostupu: http://nbuv.gov.ua/ UJRN/NaUKMAun 2013 144-145 13

10. Pro vnesennia zmin do $\overline{\text { deiakykh }}$ zakonodavchykh aktiv Ukrainy shchodo vdoskonalennia protsedury vidvedennia zemelnykh dilianok [About modification of some legislative acts of Ukraine concerning improvement of procedure of assignment of the land plots]. Zakon Ukrainy vid 2 lypnia 2013 roku № 366-VII / Vidomosti Verkhovnoi Rady Ukrainy. 2014 r., № 17, stor. 1185, stattia 587.

11. Hultai M. Pravova vyznachenist u rishenniakh Konstytutsiinoho Sudu Ukrainy [Legal certainty in the decisions of the Constitutional Court of Ukraine] / M. Hultai, I. Kyianytsia // Visnyk Konstytutsiinoho Sudu Ukrainy. - 2012. № 5. - S. 83-93.

12. Bohachova L.L. Pryntsyp pravovoi vyznachenosti v yevropeiskomu i natsionalnomu pravi (zmistovna kharakterystyka) [The principle of legal certainty in European and national law (substantive characteristics)] / L.L. Bohachova. // Teoriia $\mathrm{i}$ praktyka pravoznavstva. - 2013. - Vyp. 2. - Rezhym dostupu: http://nbuv.gov.ua/UJRN/tipp_2013_2_74. 